\title{
Nové poznatky o terciéru a kvartéru získané geologickým mapováním okolí Lipníka nad Bečvou
}

New findings on the Tertiary and Quaternary gained by geological survey of Lipník nad Bečvou surroundings

\section{Miroslav Bubík $\square_{\rightarrow}$, Helena Gilíková1, Jiří Otava', Pavla Tomanová Petrová1, Lilian Švábenická2 , Jan Vít ${ }^{1}$}

'Česká geologická služba, Leitnerova 22, 65869 Brno

2Céská geologická služba, Klárov 3, 11821 Praha 1

\section{Key words:}

Western Carpathians, Paleogene, Neogene, Quaternary, biostratigraphy, provenience, lithology

$\square$ miroslav.bubik@geology.cz

Editor:

David Buriánek

\begin{abstract}
Detail geological survey of the Lipník nad Bečvou surroundings brought new geological informations about the area, where Variscan and Carpathian orogens touch each other by their allochthonous nappe units. Detail mapping supported by micropaleontology enabled to fix the spatial extent of the nappe remnants of the Ždanice Unit in poorly exposed areas. Southeastern outskirts of Lipnik nad Bečvou are part of the type area of the Menilite Formation defined by Glocker (1844) and one of his historical type localities near situated Simre was rediscovered. Lower Miocene strata were subdivided to the Stryszawa and Kroměřžz formations based on the provenience of clastic material: Bohemian Massif for the Stryszawa Fm. and Carpathian nappes for the Kroměřž Fm. A new occurrence of rhyolitic fine-grained volcaniclastics was discovered in the Carpathian Foredeep in Lipník nad Bečvou. Quaternary sediments are represented, first of all, by complex fluvial terrace system of the Bečva River that illustrates the evolution of landscape since the latest Early Pleistocene. Remarkable local curiosity is fresh-water limestone (travertine) in Tučin, formed at the spring of thermal mineral water.
\end{abstract}

Úvod

V průběhu let 2014 až 2017 bylo v rámci mapovacího projektu České geologické služby provedeno podrobné geologické mapování území listu 25-132 Lipník nad Bečvou v měřítku 1 : 25 000. Geologická jedinečnost území spočívá ve styku prŕikrovových jednotek variského a alpinského orogénu, kde proti sobě stojí s opačnou vergencí šupiny jesenického kulmu (např. Havíř 2018) a prŕkrov ždánické jednotky. V povrchové stavbě se výrazně projevuje deprese karpatské předhlubně protékaná řekou Bečvou a kulmský flyš tvořící pásmo Nízkého Jeseníku na SZ a elevaci kry Maleníku j. od toku Bečvy. Podložím karpatské předhlubně jsou devonské a karbonské vápence jednotky Moravského krasu. Tyto jsou kompletně zakryty až 900 m mocnou miocenní výplní karpatské předhlubně a jsou známy jen z vrtů (např. NP-767 Prosenice, Hufová 1974). Karpatská předhlubeň v Moravské bráně je vyplněna sedimenty badenského stáří. K předhlubni patří také spodnomiocenní sedimenty (stupeň karpat) pokrývající kru Maleníku na JV oblasti. Tato situace je výsledkem přesunu depocentra karpatské předhlubně na začátku středního miocénu. Strukturně nadložní jednotkou je vnější skupina karpatských př́ikrovů zastoupená ždánickou jednotkou. Vystupuje v řadě izolovaných prŕíkrovových trosek nevelké mocnosti. Pro sestavení geologické mapy byly využity veškeré výsledky předchozích regionálně geologických výzkumů, zejména mapa v měřítku 1: 50 000, list 25-13 Přerov (Pálenský 

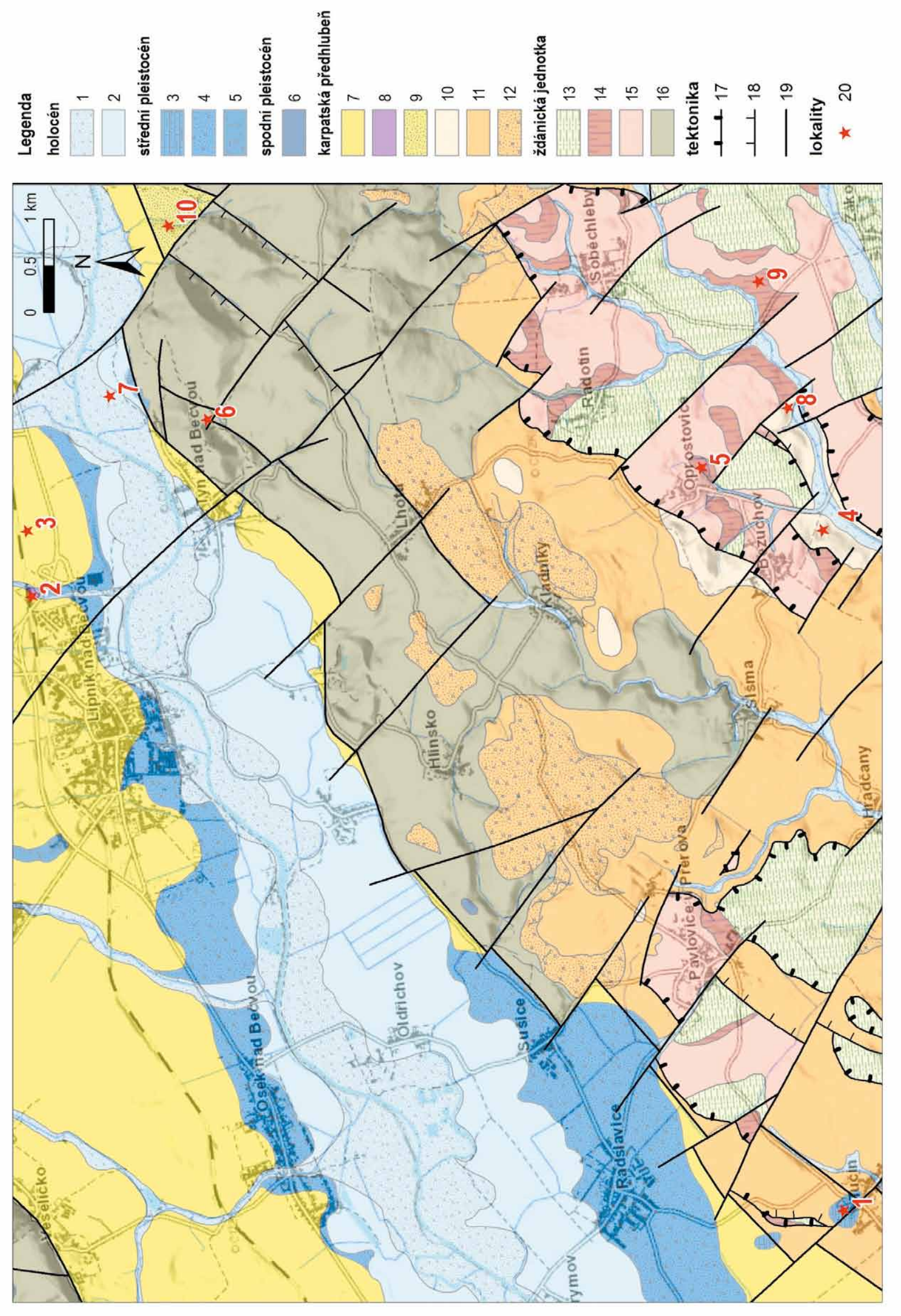
Obr. 1: Zjednodušená geologická mapa bez eolických a koluviálních pokryvů, list 25-132 Lipník nad Bečvou. Kvartér: 1 - fluviální písčitohlinité až štěrkovitopísčité sedimenty; 2 - fluviální hlinitopísčité sedimenty (vyšší nivní stupeň); 3 - travertiny; 4 - fluviální písčité štěrky; 5 - hlinité štěrky výplavových kuželů; 6 - fluviální písčité štěrky; karpatská předhlubeň, baden: 7 - šedé vápnité jíly; 8 - jemnozrnná ryolitová vulkanoklastika; 9 - slepence a pískovce (klastika); karpat: 10 - kroměřížské souvrství; 11 - stryszawské souvrství - jíly; 12 - stryszawské souvrství - štěrky a písky (klastika); ždánická jednotka: 13 - ždánicko-hustopečské souvrství; 14 - menilitové souvrství; 15 - němčické souvrství; 16 - nerozlišený kulm; 17 - násun ždánické jednotky; 18 - dílčí násun; 19 - zlom; 20 - geologická lokalita (1 - Tučín; 2 - Hlásenec; 3 - vrty HV-1013 a 3MB8; 4 - Bezuchov; 5 - Oprostovice; 6 - vrt LB28; 7 - vrt HV-1011; 8 - pískovna Símře; 9 - Símře/Glocker; 10 - Gabrielka).

Fig. 1: Simplified geological map without eolian and colluvial cover, sheet 25-132 Lipník nad Bečvou. Quaternary: 1 - fluvial sand-loamy to gravel-loamy sediments; 2 - fluvial loam-sandy sediments (higher floodplain); 3 - travertines; 4 - fluvial sandy gravels; 5 - loamy gravels of alluvial fans; 6 - fluvial sandy gravels; Carpathian Foredeep, Badenian: 7 - grey calcareous clays; 8 - fine-grained ryolite volcanoclastics; 9 - conglomerates and sandstones (clastics); Karpatian: 10 - Kroměřǐž Fm.; 11 - Stryszawa Fm. - clays; 12 - Stryszawa Fm. - sands and gravels (clastics); Ždánice Unit: 13 - Ždánice-Hustopeče Fm.; 14 - Menilite Fm.; 15 - Němčice Fm.; 16 - undivided Culmian; 17 - overthrust of the Ždánice Unit; 18 - second order overthrust; 19 - normal fault; 20 - geological locality (1 - Tučín; 2 - Hlásenec; 3 - boreholes HV-1013 and 3MB8; 4 - Bezuchov; 5 - Oprostovice; 6 - borehole LB28; 7 - borehole HV-1011; 8 - Símře sand pit, 9 - Símře/Glocker; 10 - Gabrielka).

et al. 1997). Značné plochy této mapy však byly shrnuty do nerozlišených eluvií, což odporuje současné metodice mapování. První dvě terénní sezóny nového mapování ukázaly na omezené možnosti mapování podle litologie, nebot pelity různých souvrství byly často makroskopicky nerozlišitelné. Extenzivní využití mikropaleontologie pomohlo zařadit sedimenty $\mathrm{k}$ jednotlivým souvrstvím a přineslo nové poznatky o geologické stavbě území.

\section{Metodika}

Geologické mapování se řídilo platnou metodikou ČGS pro geologické mapy 1 : 25000 (Hanžl et al. 2009). Výsledná geologická mapa se opírá o terénní pozorování a analytická data z 867 dokumentačních bodů zaznamenaných v databázi dokumentace geologického mapování ČGS.

$\mathrm{K}$ interpretaci zlomové sítě byl využit digitální model reliéfu 4. generace (DMR 4G), který je založen na datech pořízených metodou leteckého laserového skenování (Lidar). Nasvícení modelu ze čtyř světových stran zvýraznilo významnější zlomy. Méně významné zlomy byly většinou doloženy detailním petrografickým mapováním a pomocí biostratigrafie. Bylo realizováno 24 mělkých vrtů s hloubkou 2 až $9 \mathrm{~m}$ šnekovým vrtáním soupravou Lumesa. Dále bylo vyhloubeno 126 ručních vrtů vyvrtaných edelmanovým vrtákem s dosahem do $1 \mathrm{~m}$ umožňujícím odběr vzorků vhodných pro mikropaleontologické vyhodnocení.

Vzorky jílů a písků pro mikropaleontologické studium byly dezintegrovány v roztoku jedlé sody a plaveny na sítech o velikosti ok $0,063 \mathrm{~mm}$ v mikropaleontologické laboratoři ČGS v Brně. Nanofosílie byly separovány dekantační metodou v laboratoři ČGS na Barrandově.

Pro studium průsvitné těžké frakce byly vzorky plaveny na sítech. V laboratořích ČGS Barrandov byly Z velikostní frakce $0,06-0,25 \mathrm{~mm}$ separovány těžké minerály v ACTB $\left(\mathrm{C}_{2} \mathrm{H}_{2} \mathrm{Br}_{4}\right)$ o měrné hmotnosti $2,96 \mathrm{~g} . \mathrm{cm}^{-3}$. Průsvitná těžká frakce byla určována a vyhodnocována v mineralogickém mikroskopu Amplival. Kvantitativní zhodnocení každého vzorku se opírá o 200 až 700 identifikovaných zrn. Výbrusy z pevných hornin byly zhotoveny v laboratořích ČGS a ve firmě DIATECH s. r. o. v Praze. Výbrusy byly studovány na mikroskopu Nikon
Eclipse ME600 a mikrofotografie pořízeny kamerou Nikon DS-Fi2.

\section{Výsledky}

Během geologického mapování bylo rozlišeno 33 litologických položek, které jsou zobrazeny ve finální mapě (Bubík et al. 2018a, b). Přehlednější znázornění geologické stavby území ukazuje mapa po odkrytí rozsáhlých eolických a koluviálních pokryvů (obr. 1). Rovněž nejsou rozlišeny kulmské formace Nízkého Jeseníku a Maleníku, které nejsou předmětem tohoto článku. Vzájemné vztahy, stratigrafie a mocnosti sedmnácti položek zjednodušené mapy jsou zřejmé z litostratigrafického schématu (obr. 2).

\section{Karpatský flyš - ždánická jednotka}

Sedimentární náplň př́k rovových trosek ždánické jednotky je zastoupena němčickým, menilitovým a ždánicko-hustopečským souvrstvím.

\section{Němčické souvrství}

$\mathrm{V}$ němčickém souvrství zcela převažují nevápnité jíly šedých a zelenošedých odstínů. Vápnité jíly a světle šedé slíny se vyskytují podřízeně v rámci celého souvrství, ale zejména $\mathrm{v}$ nejvyšší části, kterou lze přiřadit $\mathrm{k}$ šešorským slínům. Ojediněle se vyskytly tmavošedé nevápnité jíly redukční facie (sensu Stráník et al. 1993) v Pavlovicích a šedočervené nevápnité jíly v. od Símře. Místy jíly obsahují vložky vápnitých prachů, pískovce však zjištěny nebyly. Mikropaleontologicky bylo doloženo stáří v rozsahu paleocén? až svrchní eocén. $Z$ vůdčích mikrofosilií byly zjištěny aglutinované foraminifery Trochamminopsis altiformis (C. et R.), Haplophragmoides mjatliukae Masl., Verneuilinula propinqua (Br.) svědčící pro paleocén(?). Nanofosílie Chiasmolithus cf. eograndis, Ch. minimus-titus, Ch. solitus, Ch. ex gr. nitidus dokládají lutet. Foraminifery Acarinina medizzai (T. et B.), Reticulophragmium amplectens (Grzyb.), Ammodiscus latus Grzyb dokládají barton a Pseudohastigerina naguewichiensis (Mjatl.), Turborotalia ampliapertura (Bolli), Tenuitella gemma (Jenk.) dokládají priabon.

\section{Menilitové souvrství}

Menilitové souvrství je zastoupeno podrohovcovým, rohovcovým, dynowským a šitbořickým členem. Pro 


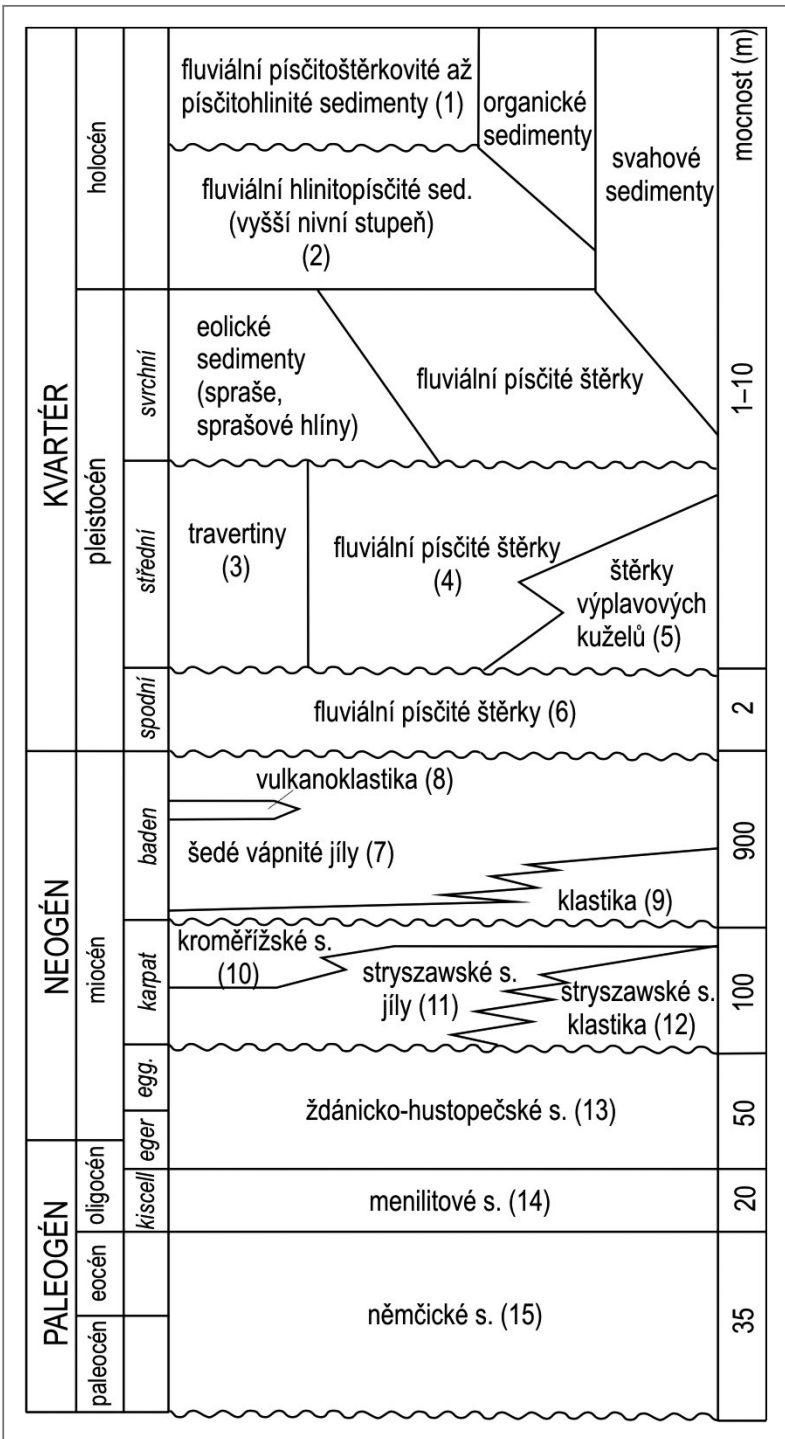

Obr. 2: Litostratigrafické schema paleogénu až neogénu karpatské předhlubně, ždánické jednotky a kvartérního pokryvu na území mapového listu Lipník nad Bečvou (čísla v závorkách představují čísla položek legendy viz obr. 1).

Fig. 2: Lithostratigraphic chart of Paleogene to Neogene formations of the Carpathian Foredeep, Ždánice Unit and Quaternary cover on the map sheet Lipník nad Bečvou (the numbers in brackets represent the item numbers of the legend, see Fig. 1).

podrohovcový člen na bázi souvrství jsou typické hnědošedé světle skvrnité a laminované slíny a hnědožluté vápnité jíly s hojnou mikrofaunou (planktonické i bentosní foraminifery). Nadložní rohovcový člen charakterizují bělavě nebo šedě navětralé, za čerstva světle šedé až hnědé, páskované, laminované i masivní menilitové rohovce doprovázené hnědošedými nevápnitými jíly a jílovci, lístkovitě rozpadavými s ojedinělými kostmi a šupinami ryb. Výše leží dynowský člen $s$ převahou světle hnědošedých až béžových slínovců, místy prokřemenělých, s pásky menilitových rohovců. Fosilní záznam reprezentuje masový výskyt nanofosílií Reticulofenestra ornata, doprovázený vzácnými exempláři Reticulofenestra minuta a Pontosphaera pulcheroides, ostrakody, makroskopickými zbytky ryb a horizonty se stopami Pilichnus. Ve výbrusu byly zjištěny hojné průřezy rekrystalovaných schránek

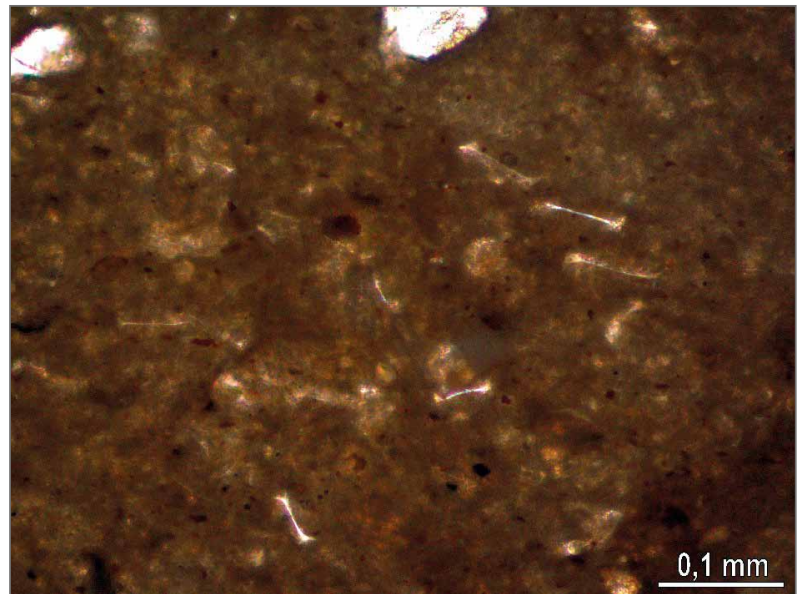

Obr. 3: Deformované centrické rozsivky ve výbrusu prokřemenělého dynowského slínovce, Soběchleby, PPL.

Fig. 3: Deformed centric diatoms in thin section of the silicified Dynow Marlstone, Soběchleby, PPL.

rozsivek (obr. 3), méně lasturky ostrakodů, ojediněle úlomky rybích kostí. V hornině jsou hojně vtroušeny velmi drobné krychlové krystaly pyritu.

Šitbořický člen charakterizuje šlírovité střídání šedě navětralých, za čerstva šedých, tmavošedých a šedohnědých laminovaných jílı̊, místy s laminami bělavého pelagického vápence a vápnitého prachu. Tyto sedimenty byly pozorovány v zářezu poldru (lokalita Oprostovice). Kšitbořickému členu lze počítat také žlutohnědě navětralé dolomitické vápence až dolomity od Oprostovic a bělavé vápence zagorzského typu od Soběchleb, vyskytující se v úlomcích na polích. Fosilní obsah šitbořického členu je zastoupen bentickými i planktonickými foraminiferami, vápnitým nanoplanktonem s Cyclicargolithus abisectus, pyritovými jádry diatom Odontella sp. a izolovanými zbytky ryb.

Jihovýchodní cíp území mapového listu je součástí typové oblasti menilitového souvrství (Glockera 1844). Během geologického mapování se podařilo identifikovat jednu z jeho historických lokalit u Símře („Abhange eines Hügels worauf der L'Hotter-Hof steht ... an der Seite gegen

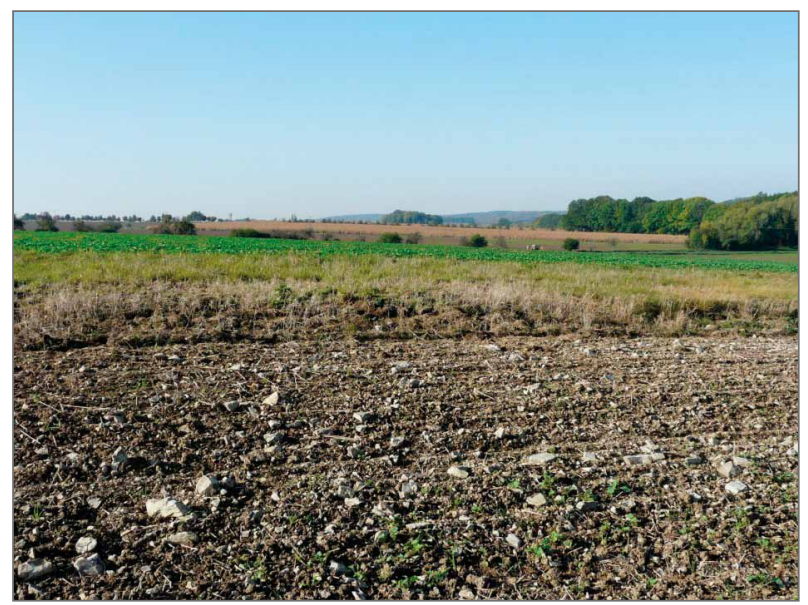

Obr. 4: Úlomky dynowského slínovce na poli u zaniklé osady Símře.

Fig. 4: Fragments of the Dynów Marlstone on the field near the abandoned settlement Símře. 
Simrže"), která byla dosud nezvěstná (Bubík et al. 2016). Nachází se na j. okraji široké ronové rýhy v úbočí hřbetu jv. od dnes zaniklé osady Símře (GPS souřadnice: $\mathrm{N} 49^{\circ}$ $27^{`} 49.0^{\prime \prime} \mathrm{E} 17^{\circ} 39^{`} 05.4^{\prime \prime}$; obr. 4). Na povrchu pole se zde vyskytují hojné úlomky pevného, destičkovitě rozpadavého šedohnědého slínovce, laminovaného menilitového rohovce a střrípky světle hnědošedého slínu s mikrofaunou foraminifer: Globoturborotalita ouachitaensis (H. et W.), Globigerina officinalis Subb., Bolivina dilatata Rss., Cibicidoides lopjanicus (Mjatl.), Cibicides amphisyliensis (Andr.). Výchozy pozorovány nebyly, ačkoli se nejspíše nacházejí mělce pod povrchem. Úlomky hornin na povrchu patří pravděpodobně dynowskému a šitbořickému členu.

\section{Ždánicko-hustopečské souvrství}

Ždánicko-hustopečské souvrství je tvořeno převážně světle šedými a šedými vápnitými jíly, slíny, jílovci a prachovci a jen podřízeně šedými jemnozrnnými pískovci ždánického typu. Jemnozrnné pískovce jsou tvořeny převážně křemenem, dále pak slídami, živci a úlomky mikritových vápenců a rul. Ojediněle byl zaznamenán glaukonit. Pojivo má bazální charakter a je tvořeno karbonátovým tmelem. Pískovce se vyznačují, podobně jako východněji na listu Kelč (Otava et al. 2016), dominancí granátů $\mathrm{v}$ průsvitné těžké frakci. $Z$ dalších minerálů je stabilně zastoupen rutil, apatit, zirkon, staurolit, turmalín, amfibol, epidot, kyanit a akcesoricky ještě sillimanit, chromspinel, titanit, glaukofan, brookit, anatas, alterit, sagenit a monazit.

Jíly obsahují foraminifery, radiolarie, jehlice hub, zuby ryb, rozsivky a vápnité nanofosílie. Planktonické foraminifery Ciperoella gr. ciperoensis (Bolli), C. anguliofficinalis (Blow) a Tenuitella angustiumbilicata (Bolli) dokládají nižší eger. Asociace s hojnou Cassigerinella chipolensis (C. et. P.) lze řadit do svrchního egeru. Nejmladší asociace s C. chipolensis (C. et. P.), Elphidium ortenburgense (Egger) a nanofosílií Helicosphaera ampliaperta patří k eggenburgu.

Během mapování se ukázalo, že šedočervené jíly karpatu a němčického souvrství jsou makroskopicky

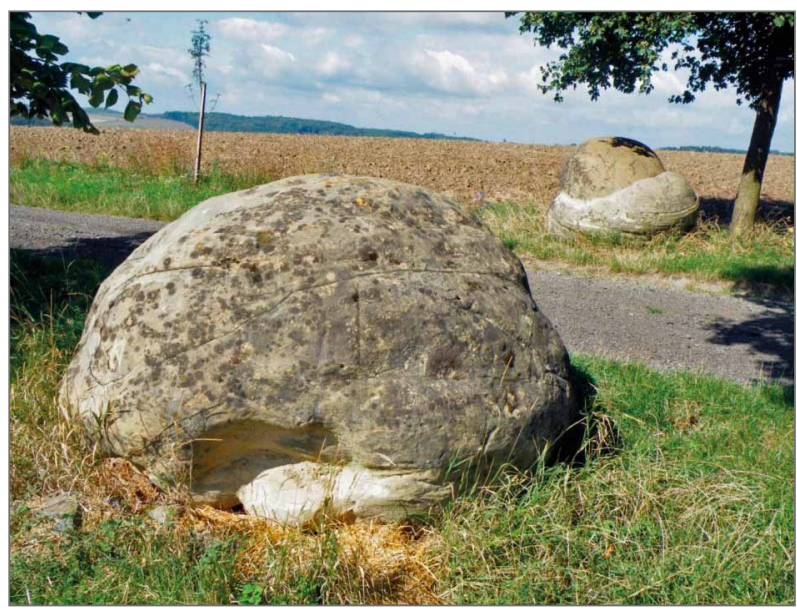

Obr. 5: Pískovcové koule (vápnité konkrece) z písků kroměřížského souvrství pocházející ze zavezené pískovny v Bezuchově. Fig. 5: Sandstone balls (calcareous concretions) from the Kroměříž Formation, extracted from the Bezuchov sandpit. nerozlišitelné. V případě šedých jílů mohly být bez dalších indicií vzájemně zaměněny němčické souvrství, šitbořické vrstvy, hustopečské slíny a karpat. Extenzivní mikropaleontologické vyhodnocení pelitů umožnilo správně rozhodnout jejich litostratigrafickou příslušnost. Na základě těchto výsledků bylo revidováno rozšíření prŕíkrovových trosek v okolí Lipníka nad Bečvou.

\section{Karpatská předhlubeň}

Miocenní sedimenty karpatské předhlubně pokrývají jednotky moravskoslezského paleozoika na většině plochy území vyjma okraje Nízkého Jeseníku v sz. cípu listu a vyzdvižené kry Maleníku, kde byly zčásti denudovány. Starší jv. zóna předhlubně je vyplněna sedimenty karpatu, které patrně nepřesahují mocnost 100 m. Mladší sz. zóna předhlubně obsahuje sedimenty badenského stáří.

Sedimentace během karpatu byla na jv. okraji kry Maleníku dotována klastickým materiálem z karpatských př́krovů, jak dokládá složení valounového materiálu. Výsledkem jsou tělesa písků a štěrků s polohami pestrých vápnitých jílů, které označujeme jako kroměřížské souvrství (Benada, Kokolusová 1987). Písky a štěrky místy uzavírají diagenetické hlízovité konkrece vápnitého pískovce a slepence o průměru až $3 \mathrm{~m}$ (obr. 5). Četné konkrece vytěžené v dnes již aplanované pískovně u Bezuchova jsou rozmístěny na veřejných plochách obcí i volně v krajině. V současnosti je reprezentativní lokalitou kroměřižského souvrství pískovna u zaniklé osady Símře (obr. 6; viz také on-line databáze geologických lokalit ČGS https://mapy.geology.cz/geologicke_lokality). Lokalita již byla studována z hlediska detritických granátů (Francírek, Nehyba 2017). Vložky vápnitých jílů obsahují marinní foraminiferovou mikrofaunu karpatu s poměrně hojnými redepozicemi z karpatského flyše.

Severozápadní část kry Maleníku pokrývají sedimenty karpatu, které byly dotovány od SZ klastickými zdroji na Českém masivu. Litologicky je lze charakterizovat jako vápnité písky, štěrky, jíly a silty. Tyto sedimenty

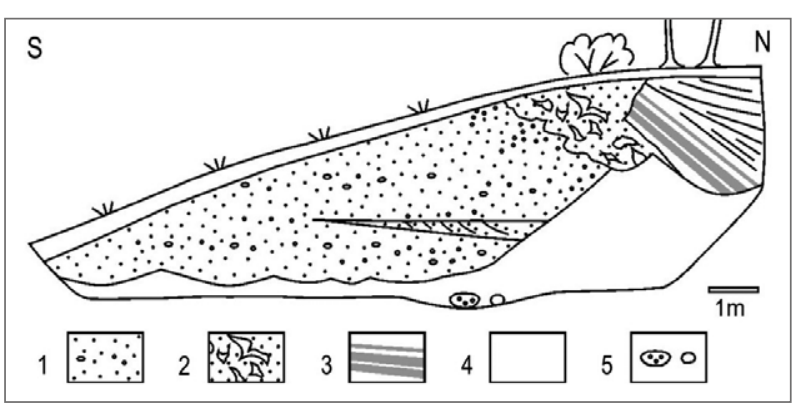

Obr. 6: Kroměřížské souvrství (karpat) odkryté v pískovně Símře: 1 - středno- až hruborznné písky a písčité štěrky s erozním korytem; 2 - jemnozrnný vápnitý písek se závalky jílovitých prachů; 3 - šedočervené a světle šedé vápnité jíly; 4 - svahoviny a sut'; 5 - uvolněné vápnité konkrece.

Fig. 6: The Kromerříž Formation (Karpatian) excavated at the Símře sandpit: 1 - medium to coarse-grained sand and sandy gravel with erosional channel; 2 - fine-grained calcareous sand with intraclasts of clayey silt; 3 - grey-red and light grey calcareous clay; 4 - loam and debris; 5 - free calcareous concretions (sandstone balls). 


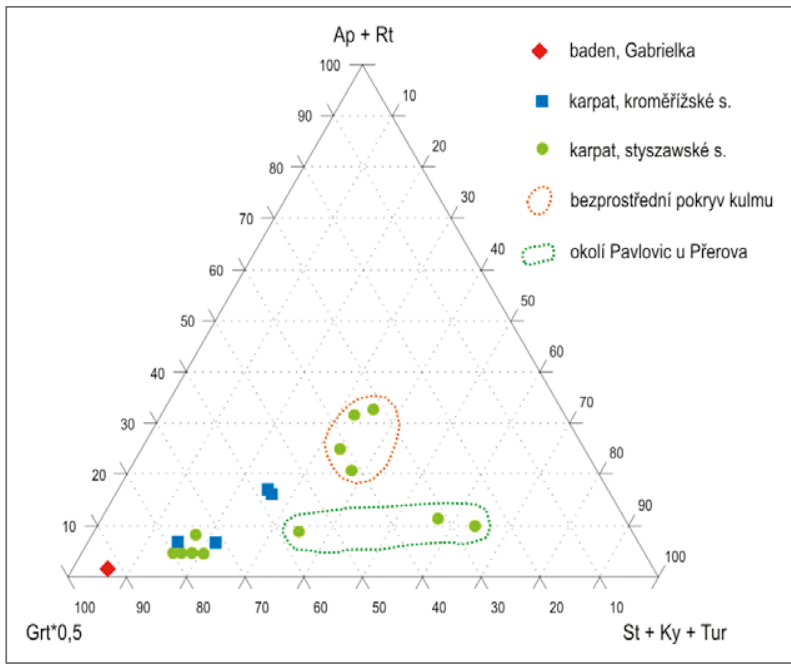

Obr. 7: Složení asociací průsvitných těžkých minerálů v sedimentech miocénu jižně od Lipníka nad Bečvou: Ap + Rt - součet obsahů apatitu a rutilu; $\mathrm{St}+\mathrm{Ky}+\mathrm{Tur}-$ součet obsahů staurolitu, kyanitu a turmalínu; Grt ${ }^{\star} 0,5$ - obsahy granátů dělené dvěma. Fig. 7: Composition of assembleges of translucent heavy minerals in Miocene sediments south of Lipník nad Bečvou: Ap + $\mathrm{Rt}$ - sum of apatite and rutile content; St + Ky + Tur - sum of staurolite, kyanite and tourmaline content; $\mathrm{Grt}^{\star} 0,5$ - garnet content divided by two.

řadíme k stryszawskému souvrství (Ślączka 1977). Vápnité jíly obsahují foraminiferovou mikrofaunu charakteristickou masovým výskytem planktonické foraminifery Cassigerinella chipolensis (C. et P.), místy doprovázené druhem Ciperoella anguliofficinalis (Blow). Stryszawské a kroměřížské souvrství se složitě laterálně zastupují, ale obecně je kroměřížské souvrství mladší.

Diagnostickým kritériem pro rozlišení obou souvrství během geologického mapování byla provenience valounů ve štěrcích, popřípadě charakter asociací průsvitných těžkých minerálů v píscích. Štěrky stryszawského souvrství obsahují klasty kulmských drob a břidlic. Štěrky kroměřížského souvrství obsahují klasty pocházející z Karpat, jako různé typy flyšových pískovců a ojediněle červený rohovec (radiolarit?). Z praktického hlediska byla při geologickém mapování kritériem především absence valounů $\mathrm{z}$ kulmu (droby, břidlice).

Určit provenienci písků je možné na základě charakteru asociací průsvitných těžkých minerálů. Písky stryszawského souvrství z v. okolí Pavlovic u Přerova mají obsahy granátů $\mathrm{v}$ některých případech pod $50 \%$ ve prospěch vyššího zastoupení typomorfních minerálů rudických vrstev (obr. 7 , tab. 1). V sestupném pořadí četnosti jsou to staurolit, kyanit, rutil, turmalín, sillimanit a andalusit. Tyto minerály tvoří u některých vzorkủ více než 40 mod. \%. Rudické vrstvy kř́ídového stáří a jejich asociaci těžkých minerálů charakterizoval Krystek (1959). Ve východní ćásti listu je vedle granátu nejvíce zastoupen rutil (místy až 15 mod. \%). Kroměřižzké souvrství postrádá enormně zvýšené obsahy typomorfních minerálů rudických vrstev (rutilu, kyanitu, staurolitu a turmalínu) a obsahy granátu se pohybují mezi 80 a 90 mod. \% (obr. 7 , tab. 1). To platí i pro oblast hlavního rozšiřrení kroměřížského souvrství j. od studovaného území.

Bázi sedimentární výplně badenské části předhlubně tvoří vápnité pískovce až slepence. Byly zastiženy hlubokými vrty, napřr. NP-767 Prosenice mimo území listu, kde dosahují mocnosti $94 \mathrm{~m}$. Ve výchozech byly ojediněle pozorovány v. od Týna nad Bečvou (lokalita pod lesní cestou Gabrielka). V r. 2007 byly rovněž odkryty na horní etáži velkolomu Podhůra. Litologicky se jedná o velmi hrubozrnný písek až pískovec nebo drobnozrnný štěrk až slepenec $s$ valouny kulmských drob a břidlic, vápenců

Tab. 1: Průsvitné těžké minerály miocenních písků z listu Lipník nad Bečvou (\%). ST - stryszawské souvrství, KR - kroměřǐžské souvrství, BK - klastické sedimenty badenu.

Tab. 1: Translucent heavy minerals of Miocene sands from the map sheet Lipník nad Bečvou (\%). ST - Stryszawa Fm., KR - Kroměříz Fm., BK - Badenian clastics.

\begin{tabular}{|c|c|c|c|c|c|c|c|c|c|c|c|c|c|c|}
\hline $\begin{array}{l}\stackrel{\Xi}{*} \\
\stackrel{\Xi}{\Xi} \\
\stackrel{\Xi}{\Xi}\end{array}$ & $\begin{array}{l}\text { lokalita, číslo dokumentačního } \\
\text { bodu v databázi ČGS }\end{array}$ & 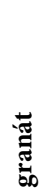 & 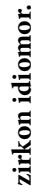 & 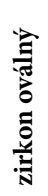 & 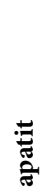 & $\bar{\Xi}$ & 罸 & $\frac{\overrightarrow{0}}{\vec{\partial}}$ & 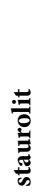 & 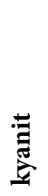 & 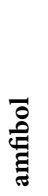 & 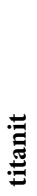 & 誌 & 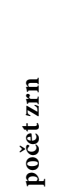 \\
\hline ST & Podolí, LB010 & 85 & 0 & 0 & 2 & 2 & 2 & 1 & 5 & 2 & 0 & 0 & 1 & 644 \\
\hline ST & Pavlovice, LO064 & 84 & 0 & 1 & 1 & 4 & 2 & 3 & 3 & 1 & 1 & 0 & 1 & 725 \\
\hline ST & Pavlovice, LO065 & 49 & 3 & 1 & 1 & 8 & 4 & 0 & 17 & 14 & 0 & 0 & 3 & 510 \\
\hline ST & Pavlovice, LO020 & 75 & 1 & 0 & 0 & 6 & 1 & 0 & 12 & 4 & 0 & 0 & 0 & 416 \\
\hline ST & Šišma, LB050B & 90 & 0 & 0 & 1 & 2 & 2 & 0 & 2 & 2 & 0 & 0 & 1 & 681 \\
\hline ST & Šišma, LB050A & 88 & 0 & 0 & 1 & 2 & 1 & 2 & 6 & 0 & 0 & 0 & 0 & 254 \\
\hline ST & Soběchleby, lom & 58 & 5 & 10 & 0 & 14 & 8 & 0 & 2 & 3 & 0 & 0 & 1 & 400 \\
\hline ST & Podhůra, LO056 & 64 & 0 & 7 & 5 & 14 & 5 & 0 & 1 & 0 & 3 & 0 & 1 & 516 \\
\hline ST & Dolní Nětčice, MB048 & 62 & 1 & 1 & 20 & 12 & 2 & 0 & 0 & 0 & 0 & 0 & 0 & 681 \\
\hline ST & Dolní Nětčice, MB050 & 62 & 3 & 4 & 17 & 11 & 2 & 0 & 0 & 0 & 0 & 0 & 0 & 577 \\
\hline ST & Přísahanec, LP120 & 37 & 8 & 4 & 0 & 7 & 7 & 1 & 19 & 13 & 1 & 0 & 3 & 476 \\
\hline KR & Žákovice, LB056 & 77 & 1 & 0 & 7 & 4 & 2 & 1 & 5 & 0 & 2 & 0 & 1 & 714 \\
\hline KR & Bezuchov, LO001 & 79 & 0 & 0 & 9 & 2 & 3 & 0 & 4 & 1 & 0 & 0 & 1 & 467 \\
\hline KR & Simře báze pískovny, LB084 & 83 & 0 & 0 & 3 & 2 & 1 & 1 & 7 & 1 & 1 & 0 & 2 & 824 \\
\hline KR & Simře vrch pískovny, LB084 & 89 & 0 & 0 & 2 & 2 & 1 & 0 & 3 & 1 & 0 & 0 & 1 & 639 \\
\hline BK & Helfštýn, Gabrielka, LG012 & 96 & 0 & 0 & 1 & 0 & 0 & 0 & 2 & 0 & 1 & 0 & 1 & 355 \\
\hline
\end{tabular}


a křemene. Pískovce a slepence jsou zrnitostně špatně vytříděné, opracovanost klastické složky je dobrá až velmi dobrá. Ve slepenci výrazně dominuje zastoupení horninových úlomků nad zastoupením minerálních klastů (85 : 15). Jsou zastoupeny (v sestupném pořadí) úlomky karbonátů, granitoidy, svory s granátem, kvarcity, fylity, kyselými vulkanity, vápnitými prachovci a pískovci. V asociaci průsvitných těžkých minerálů dominuje velmi výrazně granát (96 mod. \%) nad staurolitem (necelá 2 mod. \%). Akcesoricky se vyskytuje kyanit, chromspinel, apatit, sagenit a turmalín (obr. 7, tab. 1).

Většinu mocnosti výplně badenské části předhlubně tvoří vápnité jíly s vložkami písků. Foraminiferová mikrofauna ukazuje na značné hloubky sedimentace v centrální části pánve. Ze stratigraficky významných druhů lze uvést planktonické foraminifery Orbulina suturalis Brönn. a Praeorbulina glomerosa circularis (Blow). Vápnité jíly badenu byly ojediněle zjištěny na kře Maleníku. V sedle bezprostř̌edně jv. od hradu Helfštýn byly navrtány mapovacím vrtem LB28 pod 8,4 m mocnou sprašovou hlínou. To je výškově zhruba $100 \mathrm{~m}$ nad povrchem badenské výplně v Moravské bráně.

Důležitým nálezem byla ryolitová vulkanoklastika v nárazovém břehu potoka Hlásenec v. od Lipníka nad Bečvou. Neúplnou mocnost vulkanoklastik lze odhadnout na více než $8 \mathrm{~m}$. Kontakt s podložím ani nadložím nebyl v zářezu pozorován. Dá se předpokládat, že jde o horizont uvnitř vápnitých jílů badenu (doložen dalšími vrty v okolí). Ve výchozu převažuje světle zelenošedý jemnozrnný, místy páskovaný ryolitový tuf. Na mikroskopickém složení se podílejí převážně ostrohranné střípky vulkanického skla, hojné jsou i úlomky krystalů živců a křemene a jílové minerály v základní hmotě. Střípky skla představují drt pemzy a nejeví známky spečení. Chemickým složením tuf odpovídá ryolitu (Bubík et al. 2018a). Podřízeně byla ve výchozu pozorována pevná, střepovitě rozpadavá vulkanoklastika (tufity?). Ryolitová vulkanoklastika byla pravděpodobně zjištěna již dříve v nedalekých vrtech HV-1013, HV-1011 a 3MB8 v mocnosti přesahující $4 \mathrm{~m}$.

\section{Tektonika flyše a karpatské předhlubně}

V sedimentech karpatské předhlubně a ždánické jednotky nebyla provedena analýza strukturních prvků vzhledem k naprostému nedostatku měřitelných výchozů (zhruba 10 měření vrstevnatosti). Z vyhodnocení DMR jsou dobře patrné zejména morfologické projevy okrajových zlomů v prostoru Moravské brány. Z DMR byly místy patrné rovněž projevy radiálních zlomů orientace SZ-JV. Obecně však zlomová stavba v tzv. karpatské části předhlubně a na ní ležících trosek ždánického př́íkrovu vyplynuly z detailního mapování. V troskách ždánické jednotky byly zaznamenány brachyantiklinální uzávěry v okolí Soběchleb, dokládající vrásovou stavbu. Trosky jsou porušeny nepochybně i četnými dílčími násuny, které je však obtížné doložit při absenci větších výchozů. Podél dílčích násunů jsou do prríkrovových trosek z podloží vytaženy šupiny karpatských sedimentů, jako např. u Pavlovic.
Na kře Maleníku v okolí Týna nad Bečvou byly zjištěny zajímavé doklady výzdvihu některých ker paleozoického fundamentu. Pod lesní cestou Gabrielka byly pozorovány výchozy slepenců spodního badenu, které jsou jinak v prostoru Moravské brány pohřbeny až $800 \mathrm{~m}$ mocnými vápnitými jíly („tégly“). Dalším prríkladem badenských sedimentů ve velké relativní výšce jsou tégly ve vrtu LB28 na Helfštýně (viz výše).

Za zmínku stojí rovněž výskyt strmého uložení horizontu ryolitových vulkanoklastik v zářezu potoka Hlásenec. Na dobře zřetelné laminaci byl naměřen úklon $78^{\circ} \mathrm{k} \mathrm{SZ}$. Na malém výchozu však nelze rozhodnout, zda tento úklon je způsoben zvrásněním vrstev nebo je to důsledek nějaké gravitační deformace.

\section{Kvartérní pokryv}

Kvartérní pokryv na území mapového listu tvoří především sedimenty fluviální, eolické a svahové. Plošně sice převažují, ale jen výjimečně dosahují dosahují mocnosti $15 \mathrm{~m}$ s výjimkou sesuvů, jejichž smykové plochy v badenských sedimentech bývají založeny hlouběji.

Za nejdůležitější, $\mathrm{z}$ pohledu dešifrování geologického vývoje a časového zařazení procesů, jsou sedimenty fluviální. Jejich nejstarší akumulace, které byly původně součástí významnějších pokryvů, se nacházejí v několika skromných zbytcích na nevelkých plošinách tvořících vrcholy kopců ssv. od Tučína a sv. od osady Kudlov mezi obcemi Sušice a Hlinsko. Svojí pozicí v relativní výšce $60 \mathrm{~m}$ nad dnešním korytem řeky Bečvy naznačují, že by mohly pocházet $\mathrm{z}$ nejmladší části spodního pleistocénu. Zbytek fluviálních sedimentů nad tratí u železniční zastávky Osek nad Bečvou, mocný přibližně $8 \mathrm{~m}$, svědčí o významném zahloubení Bečvy až na výškovou úroveň cca 20 m nad dnešním korytem. Svojí pozicí odpovídá lukovské terase, kterou Macoun et al. (1966) řadí do nejstarší části středního pleistocénu. Další, již i morfologicky zřejmé terasové akumulace, lemují souvisle dnešní koryto Bečvy. Nejstarší z nich bývá označována jako radslavická (Tyráček 1957). Je vyvinuta na obou březích řeky; na levém břehu od obce Sušice přes Radslavice až dále $\mathrm{k}$ Přerovu a na pravém břehu je situace komplikována značným překrytím spraší prakticky na celém povrchu. Báze terasy se nachází v úrovni široké nivy a povrch až kolem 10 m nad ní. Stratigraficky je řazena do mladší části středního pleistocénu. Sedimenty vyplňující prostor mezi nivou a erozním zářezem údolního dna jsou tvořeny dvěma akumulacemi. Objemově mohutnější štěrková akumulace začala ve svrchním pleistocénu vyplňovat prostor údolního dna a pokračovala až do holocénu. Tato hranice se patrně nachází v blízkosti úrovně odpovídající dnešní hladině podzemní vody, kde byly zjištěny jemnozrnnější sedimenty bohaté organickou hmotou, která byla podrobena palynologickému výzkumu (Vít et al. 2019). Holocenní štěrková sedimentace postupně zjemňovala přes písčitou do tzv. nivních hlín. Během atlantiku došlo k opětovné erozi, která sice plošně nedosáhla eroze svrchnopleistocenní, ale hloubkově se jí prriblížila na $1-2 \mathrm{~m}$. Následná štěrková akumulace s hojností subfosilních kmenů, především dubů, opět př̀šla do sedimentace s převahou 


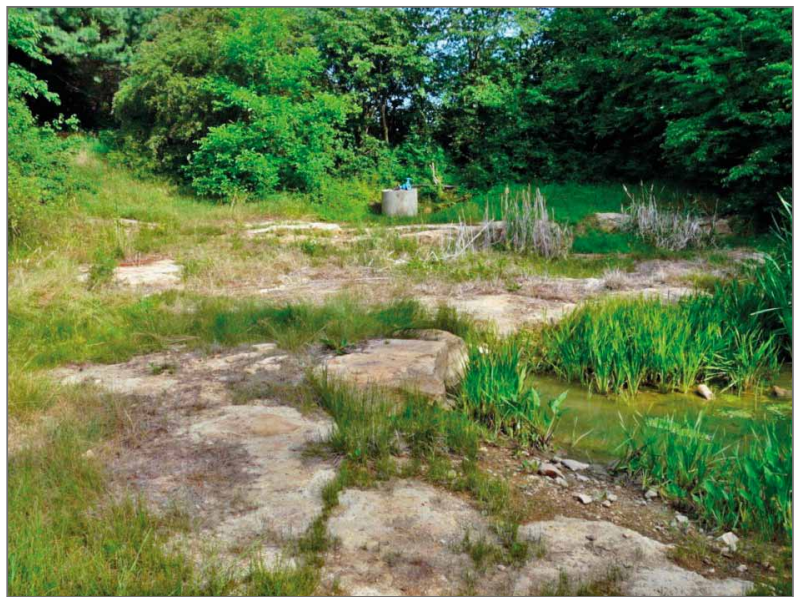

Obr. 8: Sladkovodní vápence (travertiny) v bývalém lomu v Tučíně s vývěrem termální minerální vody.

Fig. 8: Freshwater limestone (travertine) in abandoned quarry in Tučín with spring of thermal mineral water.

nivních hlín, tentokrát již ale v mocnosti, která nepřesahuje $2 \mathrm{~m}$. Tato akumulace bývá označována jako nižší nivní stupeň a dnešní koryto Bečvy, s hloubkou do $4 \mathrm{~m}$, je zahloubeno do jejího povrchu. Na rozdíl od povrchu vyššího nivního stupně, který bývá zaplavován jen v př́ípadě extrémních povodní, je její povrch zaplavován častěji.

Specifickými akumulacemi jsou hlinité štěrky na rozvodních hřbetech mezi malými toky, které přitékají z Nízkého Jeseníku. Štěrky pokrývají v širším výškovém rozsahu hřbet „Horecko“ v nadmořské výšce 290 m a další se vyskytují ve vyšších částech rozvodních hřbetů nebo na jejich svazích sz. od Lipníku nad Bečvou až do nadmořských výšek cca $265 \mathrm{~m} \mathrm{n}$. m. Jde o relikty mohutných propojených výplavových kuželů na úpatí Nízkého Jeseníku, které mohly vzniknout jako reakce na tektonickou fázi, kterou Zeman (1967) označuje jako drahanskou a zařadil ji časově na samý konec spodního pleistocénu nebo začátek pleistocénu středního. Vzhledem $\mathrm{k}$ značné náchylnosti podložních jílů $\mathrm{k}$ sesouvání, a tím destrukci nadložního pokryvu, je mladší časové zařazení pravděpodobnější.

Produkty eolického transportu a akumulace reprezentované především sprašovými hlínami pokrývají značné plochy povrchu. V okolí Lipníka nad Bečvou v nich nejsou významné odkryvy. Paleontologické ani archeologické nálezy podobné těm v nedalekém Předmostí u Přerova nejsou známy.

Svahové sedimenty jsou zastoupeny hrubozrnnějšími typy charakteru hlinitokamenitých a kamenitohlinitých uloženin, které se vyskytují především u Veselíčka a okolí kry Maleníku a jsou tedy vázané na morfologicky členitější reliéf vyvinutý na kulmských horninách. Písčitohlinité až hlinitopísčité svahové sedimenty mají vazbu především na oblasti tvořené spraší a sprašovou hlínou, sedimenty neogénu nebo eluvii hornin karpatského flyše. Nejmocnější svahoviny vznikly v souvislosti se sesuvy s hlouběji založenými smykovými plochami. Stáří sesuvů jz. od Týna nad Bečvou bylo již dříve ověreno radiometrickým datováním organického materiálu pocházejícího z bazálních částí týlních depresí a nepřesahuje cca 45 tis. let (Krejčí et al. 2008).

Významnou kvartérní pozoruhodností listu Lipník nad Bečvou jsou sladkovodní vápence (travertiny) vysrážené $\mathrm{z}$ termálního minerálního pramene u Tučína (obr. 8; viz také databáze geologických lokalit ČGS https://mapy.geology.cz/geologicke_lokality). Tvoří elevaci (kupu), ve které byly v minulosti založeny i lomy na těžbu dekoračního kamene. Hlavní masa travertinu vznikla patrně během výrazného interglaciálu ve střední části středního pleistocénu (Kheil 1965). Podle Ložka a Tyráčka (1958) mohla sedimentace probíhat ještě ve svrchním pleistocénu.

\section{Závěry}

Podrobné geologické mapování $1: 25000$ přineslo následující geologické poznatky o území mapového listu Lipník nad Bečvou:

1) Aplikace mikropaleontologie dovolila výrazně upřesnit rozšíření tektonických trosek ždánické jednotky v okolí Pavlovic u Přerova, Žákovic a Bezuchova.

2) Byla identifikována jedna $z$ historických lokalit menilitového souvrství Glockera (1844) v rámci typové oblasti souvrství. Je to stráň s výskytem úlomků hornin dynovského a šitbořického členu jv. od zaniklé osady Símře.

3) Sedimenty karpatu byly rozčleněny do stryszawského a kroměřížského souvrství na základě př́tomnosti valounů z kulmu (stryszawské s.) nebo jejich absence (kroměřížské s.). U písků byly rozlišovacím kritériem asociace těžkých minerálů typomorfních pro rudické vrstvy (stryszawské s.) nebo s vysokou převahou granátu (kroměřížské s.).

4) U Lipníka nad Bečvou byl objeven výchoz ryolitových vulkanoklastik badenu.

5) Navzdory špatné odkrytosti a totálnímu nedostatku strukturních měření byla na základě morfostrukturní analýzy digitálního modelu reliéfu (DMR G4) a podrobného mapovánís sodporou mikropaleontologie odhalena zlomová sít a vrásovo-násunová stavba uvnitř př́íkrovových trosek ždánické jednotky.

6) Fluviální terasový systém dokládá zahloubení hlavního toku minimálně $60 \mathrm{~m}$ a tím i výraznějši rozčlenění reliéfu v době od nejmladšího spodního pleistocénu do recentu. Hranice mezi svrchnopleistocénní a holocénní fluviální sedimentací byla zastižena přibližně ve výšce běžné hladiny dnešního toku řeky Bečvy.

\section{Poděkování}

Geologické mapováníbylo financováno interním projektem České geologické služby č. 321186. Autoři děkují recenzentům a editorovi za cenné pripomínky a diskusi, které zvýšily čitelnost a přehlednost článku. 


\section{Literatura}

Benada, S., Kokolusová, A. (1987). Nové poznatky o geologické pozici hrubých klastik karpatu ve střední části karpatské předhlubně na Moravě. - Zemní plyn a nafta, 32, 1, 1-15.

Bubík, M., Franců, J., Gilíková, H., Otava, J., Švábenická, L. (2016). Upper Cretaceous to Lower Miocene of the Subsilesian Unit (Western Carpathians, Czech Republic): stratotypes of formations revised. - Geologica Carpathica, 67, 3, 239-256. https:// doi.org/10.1515/geoca-2016-0016

Bubík, M., Břízová, E., Buriánek, D., Gilíková, H., Havíř, J., Janderková, J., Kašperáková, D., Knésl, I., Kolejka, V., Konečný, F., Krejčí, O., Kryštofová, E., Otava, J., Pecina, V., Pořádek, P., Sedláček, J., Sedláčková, I., Švábenická, L., Skácelová, Z., Tomanová Petrová, P., Večeřa, J., Vít, J. (2018a). Vysvětlivky k základní geologické mapě ČR list Lipník nad Bečvou 25-132. - MS [archivní zpráva], Česká geologická služba. Praha.

Bubík, M., Gilíková, H., Otava, J., Tomanová Petrová, P., Vít, J. (2018b). Základní geologická mapa České republiky $1: 25$ 000, list 25-132 Lipník nad Bečvou. - Česká geologická služba. Praha.

Databáze významných geologických lokalit [databáze online]. Praha, Česká geologická služba, 1998 [citováno 2019-10-08]. Dostupné z URL http:// lokality.geology.cz.

Francírek, M., Nehyba, S. (2017). Nové poznatky k provenienci sedimentů kroměřížského souvrství. - Zprávy o geologických výzkumech, 50, 45-49.

Glocker, E. F. (1844). Die Menilitformation in Mähren. In: Langer L. \& Schrötter A. (Eds.): Amtlicher Bericht über die einundzwanzigste Versammlung deutscher Naturforscher und Aerzte in Gratz im September 1843, 139-141, Andreas Leykam'schen Erben. Gratz.

Hanžl, P., Čech, S., Doležalová, Š., Dušek, K., Gürtlerová, P., Krejčí, Z., Kycl, P., Man, O., Mašek, D., Mixa, P., Moravcová, O., Pertoldová, J., Petáková, Z., Petrová, A., Rambousek, P., Skácelová, Z., Štěpánek, P., Večeřa, J., Žáček, V. (2009). Směrnice pro sestavení Základní geologické mapy České republiky $1: 25$ 000. - 45 s. Česká geologická služba. Praha.

Havír. J. (2018). Neogenní zpětná rotace vrásovo-násunové stavby ve spodním karbonu kry Maleníku - Geologické výzkumy na Moravě a ve Slezsku, 25, 1-2, 86-91.

Hufová, E. (1974). Radslavice NP 767. Závěrečná zpráva vrtu. Surovina-voda. Etapa-první. - MS, Česká geologická služba. 177 str. Kheil, J. (1965). Pleistocénní ostrakodi z travertinů v Tučíně u Přerova. - Věstník Ústředního ústavu geologického, 40, 409-417.

Krejčí, O., Baroň, I., Hubatka, F., Kašperáková, D., Nývlt, D. (2008). Tectonic of slopes with large block landslides on the NE margin of the Bohemian Massif. In: Jaboyedoff, M.: Slope Tectonics 2008, Lausanne, February 15-16, 2008. - Université de Lausanne, Institut de géomatique et d'analyse risque. Lausanne.

Krystek, I. (1959). Příspěvek k poznání genese a stáří rudických vrstev. - Kras v Československu, 12, 22-23.

Ložek, V., Tyráček, J. (1958). Stratigrafický výzkum travertinu v Tučíně u Přerova. - Anthropozoikum, 7, 261-286.

Macoun, J., Růžička, M., Chlupáč, I. et. al. (1966). Vysvětlivky k listu mapy 1 : 50 000, M-33-95-D Přerov. - MS, archivní zpráva. Ústřední ústav geologický. Praha.

Otava, J., Bábek, O., Bubík, M., Buriánek, D., Čurda, J., Franců, J., Fürychová, P., Geršl, M., Gilíková, H., Godány, J., Havíř, J., Havlín Nováková, D., Krejčí, O., Krejčí, V., Lehotský, T., Maštera, L., Novotný, R., Poul, I., Sedláčková, I., Skácelová, D., Skácelová, Z., Stráník, Z., Švábenická, L., Tomanová Petrová, P. (2016). Vysvětlivky k základní geologické mapě České republiky $1: 25$ 000, list 25-141 Kelč. Geologická mapa 1:25000 s textovými vysvětlivkami. Česká geologická služba. Praha. $116 \mathrm{~s}$.

Pálenský, P., Dvořák, J., Maštera, L., Svatuška, M., Tyráček, J. (1997). Geologická mapa ČR, List 25-13 Přerov. - Český geologický ústav, Praha.

Ślaczka, A. (1977). Rozwój osadów miocenu z otworu wiertniczego Sucha IG-1. - Kwartalnik Geologiczny, 21, 405-406.

Stráník, Z., Menčík, E., Eliáš, M., Adámek, J. (1993). Flyšové pásmo Západních Karpat, autochtonní mesozoikum a paleogén na Moravě a ve Slezsku. - In: Přichystal, A., Obstová, V., Suk, M. (eds), Sborník příspěvků k 90. výročí narození prof. dr. K. Zapletala, 107-122, Moravské zemské muzeum a Masarykova univerzita.

Tyráček, J. (1957). Zpráva o výzkumu a mapování čtvrtohorních pokryvných útvarů na Ostravsku za rok 1955, jihozápadní část Moravské brány mezi Lýskami a Lipníkem n. Bečvou na topograf. sekcích 4259/1 a 4159/3. - Anthropozoikum, 6, 166-172.

Vít, J., Břízová, E., Kolář, T., Rybníček, M. (2019). Organické uloženiny fluviální výplně údolního dna řeky Bečvy u Oseku nad Bečvou a jejich vztah k vývoji sedimentace. - Geologické výzkumy na Moravě a ve Slezsku, 26, 12, 66-72.

Zeman, A. (1967). Kvartérní neotektonické fáze ve východní části Vyškovského úvalu. - Věstník Ústředního ústavu geologického, 42, 105-110. 